\title{
Specific Innervation of Neurons in the Paravertebral Sympathetic Ganglia of the Chick
}

\author{
Joseph W. Yip \\ Department of Physiology, School of Medicine, University of Pittsburgh, Pittsburgh, Pennsylvania 15261
}

I have explored the chick sympathetic system as a model for the study of specific synapse formation by examining the pattern of ganglion cell innervation by preganglionic axons in 2 different ganglia. Using intracellular recording and HRP labeling techniques, the innervation of the 12th and 15th cervical ganglia (C12 and C15) was examined. Sympathetic ganglion cells of the chick are innervated in a stereotyped manner by preganglionic axons arising from different levels of the spinal cord. While each ganglion is innervated by preganglionic axons arising from several spinal cord segments, individual ganglion cells are innervated by only some of the spinal segments that supply each ganglion as a whole. The subset of spinal segments is always contiguous, with 1 segment providing the dominant innervation to the cell. Spinal segments adjacent to the dominant segment provide synaptic inputs that diminish as a function of distance from the dominant segment. This pattern of ganglion cell innervation in the chick is similar to that of the mammal, where re-innervation studies have suggested that ganglion cell innervation is selective. The similarity in the innervation of avian and mammalian sympathetic neurons suggests that the rules that underlie the specificity of synapse formation in the sympathetic system of the 2 species are the same. Because of the accessibility of the chick embryo for experimental manipulations during development, it is now possible to study the cellular basis that underlies the specificity of synapse formation in this relatively simple nervous system.

Neurons in the paravertebral sympathetic ganglia of mammals are selectively innervated by preganglionic axons arising from different spinal cord segments (Langley, 1892, 1900; Njå and Purves, 1977a; Lichtman et al., 1980). In the superior cervical ganglion of the guinea pig, for instance, ganglion cells that project to a particular peripheral target area are innervated by preganglionic axons arising from the same spinal cord segments. Segmentally selective innervation is also apparent in the rest of the sympathetic chain, where progressively more caudal ganglia are innervated by overlapping but progressively more caudal sets of preganglionic axons. The selectivity of ganglion cell innervation is maintained in the re-innervation of the superior cervical ganglion (Guth and Bernstein, 1961; Langley, 1895, 1897; Maehlen and Njå, 1981; Njå and Purves, 1977b, 1978) and in the re-innervation of ganglia transplanted to a different level of the sympathetic chain (Purves et al., 1981). An important question raised by these studies is how appropriate pre- and post-

\section{Received Dec. 30, 1985; revised May 6, 1986; accepted July 8, 1986.}

This work was supported by BNS82-10028 and by a Basil O'Connor Starter Research grant from the March of Dimes Birth Defects Foundation. I thank Dale Purves, Cynthia Lance-Jones, Jeff Lichtman, and Wes Thompson for critical comments on the manuscript, Christine Capriotti for technical assistance, Sandy Estocsin for typing the manuscript, and Bill Brent for illustrations.

Correspondence should be addressed to Joseph W. Yip at the above address. Copyright (C) 1986 Society for Neuroscience $0270-6474 / 86 / 123459-06 \$ 02.00 / 0$ synaptic neurons are recognized. Although several hypotheses on the mechanism of selective synaptogenesis in the sympathetic nervous system have been proposed (see, for example, Rubin, $1985 \mathrm{a}-\mathrm{c}$ ), the ability to test these hypotheses is limited by the inaccessibility of the mammalian embryo.

In the present study, I have examined the specificity of ganglion cell innervation in the sympathetic system of the chick. My results indicate that sympathetic ganglion cells of the chick are also innervated in a segment-specific fashion by preganglionic axons (see also Langley, 1904). The general resemblance of the sympathetic system of the chick and the mammal suggests that the rules that underlie the specificity of the sympathetic system in the 2 species are the same. Because of the accessibility of the chick embryo and the possibility of surgical manipulations during development, the chick sympathetic system may provide a much more tractable preparation for in vivo studies on the mechanisms of selective synapse formation. For example, in the following paper (Yip, 1986b), I describe the formation of sympathetic ganglia in the chick and examine whether position along the neural tube prior to neural crest migration is a basis for recognition between pre- and postganglionic neurons.

\section{Materials and Methods}

\section{Chick sympathetic chain ganglia}

The sympathetic chain ganglia of the chick are located along each side of the vertebral column. Ganglion cells are innervated by a column of preganglionic neurons, extending between the brachial and lumbosacral enlargements of each side of the spinal cord (Langley, 1904; Levi-Montalcini, 1950; Terni, 1923). Unlike the mammal, the chick has a sympathetic ganglion closely attached to the spinal nerve at each cervical level; at the thoracic levels, sympathetic ganglia are apposed to the dorsal root ganglia (see Fig. 1). The sympathetic trunk between successive thoracic ganglia is divided so that one branch goes above and the other below each rib. The sympathetic chain above $\mathrm{C}, 12$ is split into a major paravertebral trunk that runs along the transverse processes of the vertebrae and a minor (postcarotid) trunk that lies adjacent to the carotid artery (see Yntema and Hammond, 1947). Because of the branching of the sympathetic trunk above $\mathrm{C} 12$ and the absence of rami communicantes at thoracic levels, only the lower cervical ganglia $(\mathrm{Cl} 2-\mathrm{Cl}$ ) are readily accessible for recording ganglion responses to segmental stimulation (Lichtman et al., 1980; Njá and Purves, 1977a). For this reason, I have focused on the innervation of the 12th and 15th cervical ganglia ( $\mathrm{Cl} 2$ and $\mathrm{C} 15$ )

\section{Intracellular recording from ganglion cells}

Intracellular recordings were made from sympathetic ganglion cells of 1- to 2-month-old White Leghorn chicks. In a manner similar to such studies in mammals ( $\mathrm{Nja}$ and Purves, 1977a), the right 12th or 15th cervical ganglion ( $\mathrm{C} 12$ or $\mathrm{C} 15)$ was removed from anesthetized chicks along with the thoracic portion of the sympathetic chain and the adjoining ventral roots. The preparation was placed in a bath and perfused with oxygenated Tyrode solution (Ginsborg, 1960) at room temperature. Ventral roots C15-T4, which contribute to the innervation of both ganglia, were taken up into suction electrodes for stimulation $(0.5 \mathrm{msec}$ 
Figure 1. A, Chick sympathetic nervous system. Sympathetic ganglia are segmentally arranged along each side of the vertebral column. Ganglion cells are innervated by a column of preganglionic neurons that extend between the brachial and lumbosacral enlargements on each side of the spinal cord. Preganglionic axons exit in the ventral roots to innervate the sympathetic chain. In order to determine the extent and organization of the preganglionic neurons innervating the cervical sympathetic chain ganglia using retrograde HRP labeling, about $1 \mathrm{mg}$ HRP was applied to the rostral and caudal cut ends of both divisions of the sympathetic trunk just below the $\mathrm{C} 15$ ganglion (circle). Since the preganglionic column ceases at $\mathrm{C} 15$, this procedure identified all the preganglionic neurons that innervate the $\mathrm{C} 15$ and more rostral cervical ganglia. $B$, Drawing of a transverse section of the thoracic spinal cord showing the location of preganglionic neurons and their projections. Depending on the segmental origins of their cell bodies, preganglionic neurons may project in the rostral or in the caudal direction.
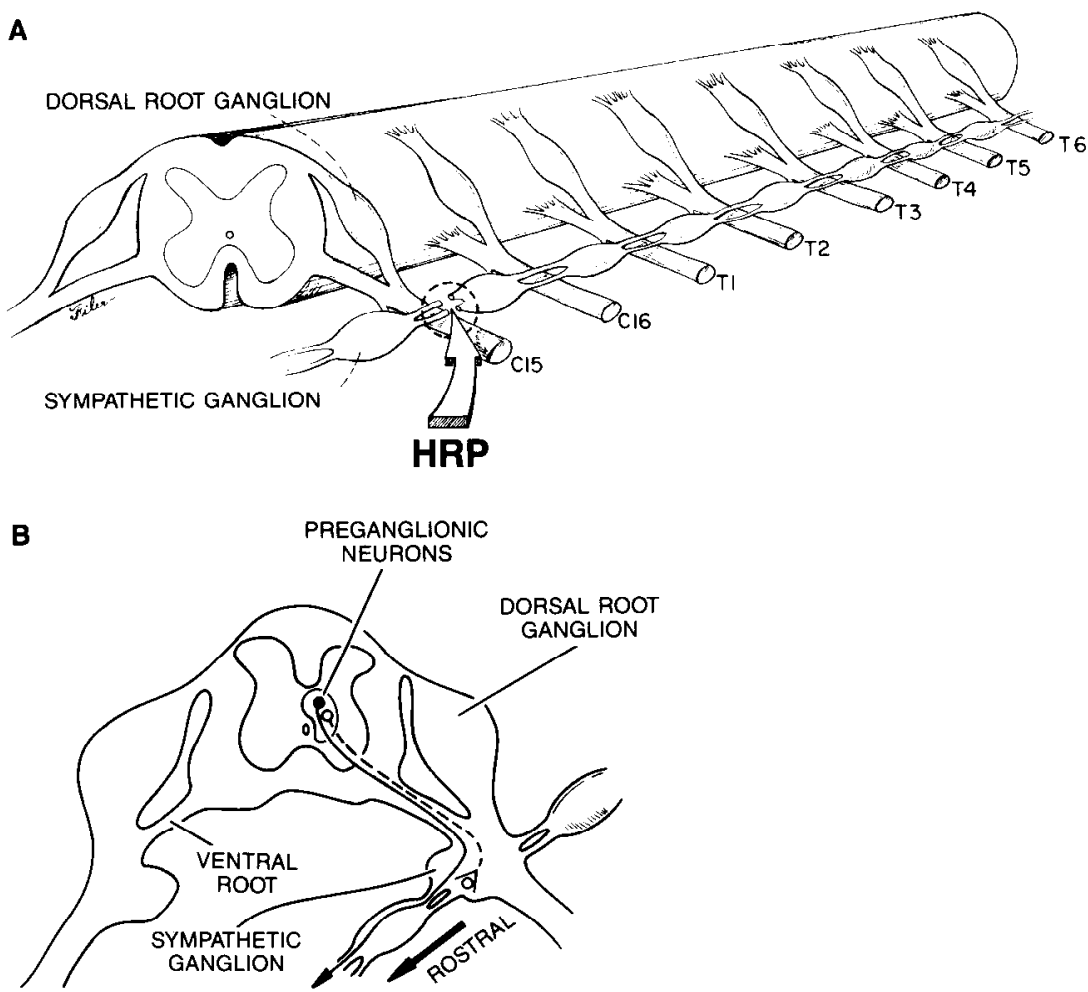

pulses, $50-100 \mathrm{~V}, 0.5 \mathrm{sec}$ ). Ventral roots anterior to $\mathrm{C} 15$ contain no sympathetic preganglionic axons. Intracellular recordings were made from individual ganglion cells while stimulating in turn each ventral root. For each cell impaled, the following parameters were determined: (1) the spinal segments innervating each cell; (2) the number of preganglionic axons innvervating each cell, as identified by the discretc stcps of synaptic potential produced by graded stimulation of each ventral root; and (3) the compound EPSP amplitude arising from supramaximal stimulation of individual ventral roots. Ten to twenty cells were impaled in each preparation.

\section{Anatomical methods}

Preganglionic neurons innervating the cervical sympathetic chain ganglia of 1 - to 2 -week-old hatchlings were identified by retrograde labeling with HRP. The cervical sympathetic trunk was exposed in animals anesthetized with pentobarbital and about $1 \mathrm{mg}$ of HRP (Sigma Type VI) was applied to the rostral and caudal cut ends of both divisions of the sympathetic trunk between the $\mathrm{C} 15$ and $\mathrm{Cl} 6$ ganglia (Fig. 1). Alternatively, HRP was applied to a well built with stop-cork grease around the 4 cut ends of the sympathetic trunk. No difference was found in the extent of preganglionic neurons labeled between these 2 methods of HRP application. The incision was then closed with sutures. Twentyfour hours later the animals were sacrificed and perfused through the heart with $0.5 \mathrm{M}$ PBS, followed by a phosphate-buffered fixative consisting of $1 \%$ paraformaldehyde, $2.5 \%$ glutaraldehyde, and $4 \%$ sucrose (Rubin and Purves, 1980). The spinal cord extending from C14 to T5 was removed and immersed in fresh fixative for an additional $2 \mathrm{hr}$. Thereafter, it was rinsed in phosphate buffer, equilibrated in buffered $30 \%$ sucrose, and embedded in gelatin-albumin (Rubin, 1985a). Serial transverse or horizontal sections, $30 \mu \mathrm{m}$, were made using a cryostat; these were then mounted on slides and reacted for the presence of HRP. Tetramethylbenzidine (TMB) was used as the chromogen (DeOlmos et al., 1978). Since the preganglionic cell column, in most instances, does not start until the C16 spinal segment (see below), this procedure labels all the preganglionic neurons that project to the $\mathrm{C} 15$ and more rostral ganglia.

In order to determine whether the organization of the preganglionic neurons is segmental in nature (i.e., whether preganglionic axons exit the spinal cord at the segmental level of their cell bodies-see Rubin and Purves, 1980), the T1 spinal nerves of 3 animals were cut at their exit from the vertebrae before HRP was applied to the cut cervical sympathetic trunk between the $\mathrm{C} 15$ and $\mathrm{C} 16$ ganglia. The absence of labeled neurons at $\mathrm{T} 1$ would then indicate a strictly segmental organization of preganglionic neurons. Horizontal serial sections were made from the spinal cord of this series of animals.

\section{Results}

\section{Innervation of $\mathrm{C} 12$ and C15 ganglia}

Each ganglion is innervated by preganglionic axons arising from several spinal cord segments. Individual ganglion cells, however, are innervated by only some of the spinal segments that supply each ganglion as a whole. This subset of spinal segments is always contiguous, with 1 segment providing the strongest innervation to the cell. Spinal segments adjacent to the dominant segment provide synaptic inputs that diminish as a function of their distance from the dominant segment (Fig. 2).

Impalement of 228 cells in the $\mathrm{C} 12$ ganglion indicated that it is innervated by the C15-T3 spinal segments (Fig. $3 \mathrm{~A}$ ); each ganglion cell is innervated on average by $11.2 \pm 0.2$ (SEM) axons arising from $2.6 \pm 0.04$ segments. Similar recordings from the C15 ganglion indicated that it is innervated by the C15-T4 spinal segments (Fig. $3 B$ ); each ganglion cell is innervated on average by $11.6 \pm 0.2$ axons arising from $3.5 \pm 0.06$ segments ( $n=205$ cells).

The two ganglia differ in the proportion of neurons innervated by preganglionic axons arising from different segmental levels (Fig. 3). Whereas both ganglia are innervated by almost the same set of preganglionic axons (C15-T3 for the $\mathrm{C} 12$ ganglion and $\mathrm{C} 15-\mathrm{T} 4$ for the $\mathrm{C} 15$ ganglion), a relatively larger number of $\mathrm{C} 12$ ganglion cells are innervated by preganglionic axons arising from more rostral segments. The difference in the segmental innervation of these 2 ganglia is also reflected by the preganglionic axons providing dominant innervation to each ganglion. Neurons in the more caudal $\mathrm{C} 15$ ganglion tend to be dominated more by preganglionic axons arising from more caudal spinal cord segments (Fig. 4). 


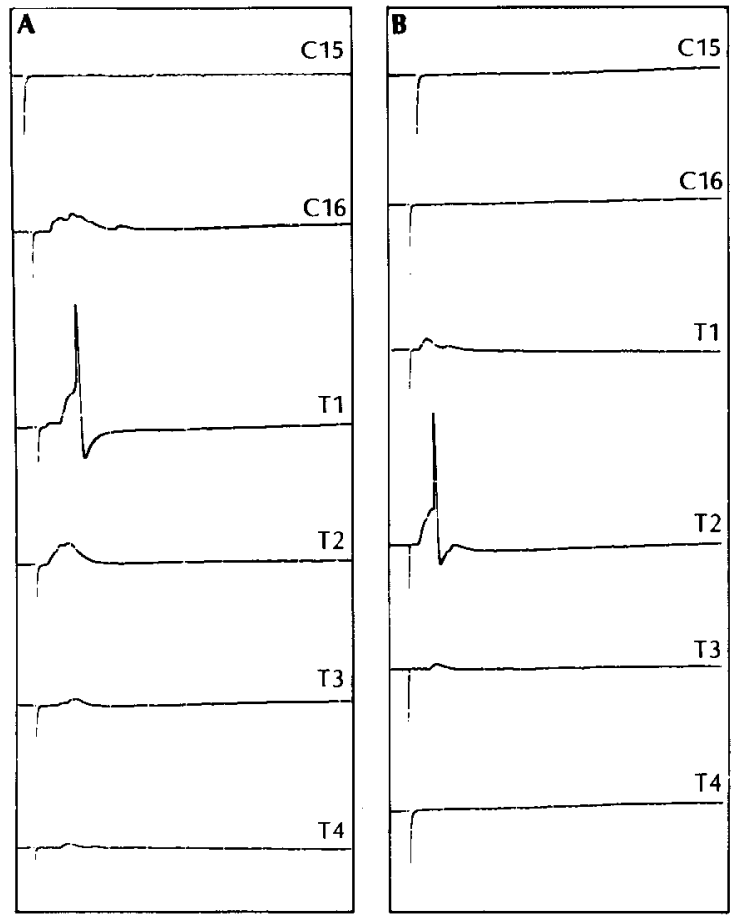

Organization of preganglionic neurons in the spinal cord

Since the preganglionic column ceases at $\mathrm{C} 15$, preganglionic neurons innervating the cervical sympathetic chain ganglia above C16 were identified by retrograde labeling with HRP applied to the cut sympathetic trunk between the $\mathrm{C} 15$ and $\mathrm{C} 16$ ganglia (Fig. 1). Nine chicks in which HRP was applied unilaterally to

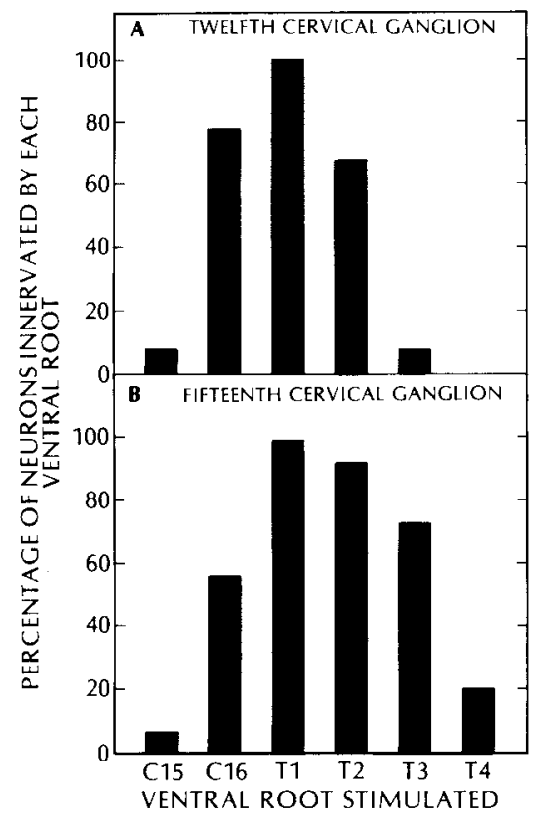

Figure 3. Segmental innervation of the $\mathrm{C} 12$ and $\mathrm{C} 15$ ganglia as determined by intracellular recording techniques. Each ganglion cell is multiply innervated by preganglionic axons arising from an average of 3-4 spinal cord segments. Although both ganglia are innervated by approximately the same set of spinal segments, cells in the more rostral $\mathrm{C} 12$ ganglion $(A)$ tend to be innervated by preganglionic axons arising from more rostral spinal cord segments than the C15 ganglion $(B)$.

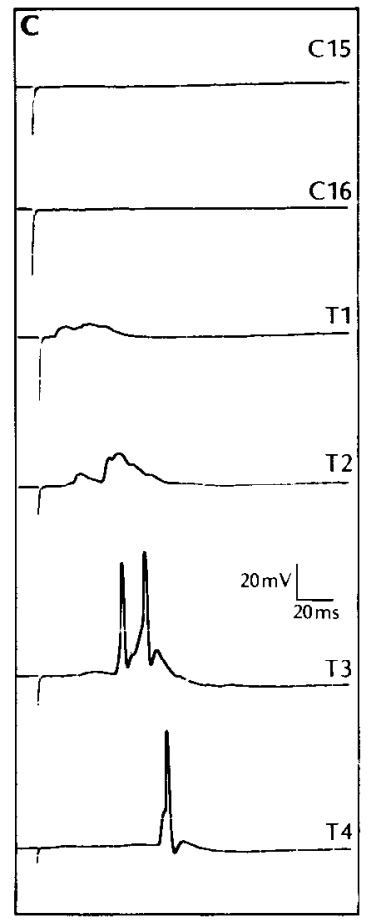

Figure 2. Examples of the innervation of 3 different cells obtained from the $\mathrm{Cl} 5$ ganglion in a single animal. Each cell receives synaptic inputs from a contiguous set of spinal segments. Moreover, a single segment provides the dominant innervation to the cell. The neurons shown in $A-C$ are dominated successively by spinal segments T1-T3. Segmental dominance, as defined by the segment providing both the largest number of preganglionic axons contacting each cell and the largest EPSP amplitude, is similar to that seen in mammals ( $\mathrm{Nja}$ and Purves, 1977). The stereotyped pattern of ganglion cell innervation in the C15 ganglion is equally evident when similar recordings are made from the C12 ganglion. the cut sympathetic trunk and an additional 2 in which HRP was applied bilaterally were studied. Labeled cell bodies were found in spinal cord segments $\mathrm{C} 15-\mathrm{T} 4$ and were restricted to the side where HRP was applied (Fig. 5). Bilateral HRP application labeled 2 cell columns, the columns of Terni, located dorsomedially in the spinal cord (see Levi-Montalcini, 1950; Oppenheim and Chu-Wang, 1983; Terni, 1923). Occasionally 1 or 2 labeled cells were found in the intermediolateral position of the spinal cord (Fig. 5C), where many preganglionic neurons of mammals are located. In each of the animals studied, the number of labeled preganglionic neurons in each spinal segment varies systematically as a function of their spinal level. The number of labeled preganglionic neurons is greatest at the T1

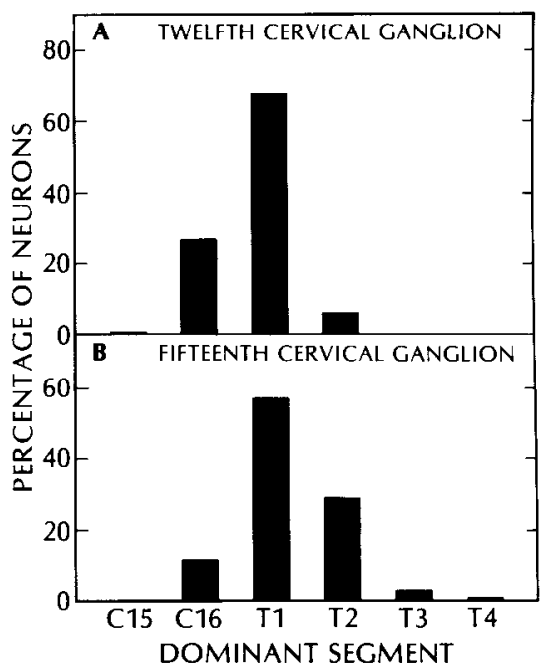

Figure 4. Distribution of segments providing dominant innervation to individual neurons in the $\mathrm{C} 12(A)$ and $\mathrm{C} 15(B)$ ganglia. Thus, within each ganglion, subpopulations of neurons receive dominant innervation from different spinal segments. The criterion of segmental dominance used here was the EPSP amplitude. 

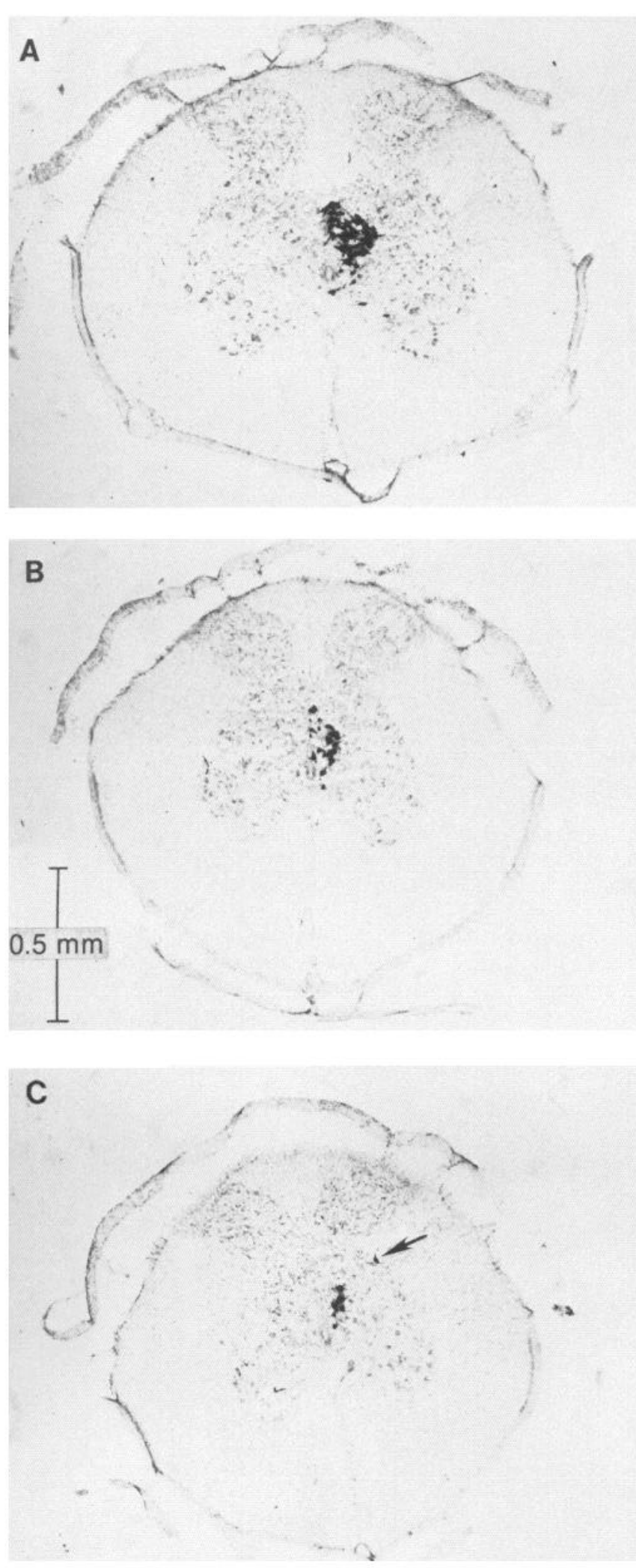

Figure 5. HRP applied to the cut cervical sympathetic trunk just below the $\mathrm{C} 15$ ganglion labels a population of preganglionic neurons (the column of Terni), extending from the $\mathrm{C} 15$ to $\mathrm{T} 4$ spinal segments. The majority of labeled neurons are found in the T1 spinal segment $(A)$, where they occupy a region of the gray matter that extends from the dorsal to the ventral funiculi. The number of labeled preganglionic neurons is substantially reduced at the T2 spinal segment $(B)$, and only a small number of labeled preganglionic neurons are found at the T3

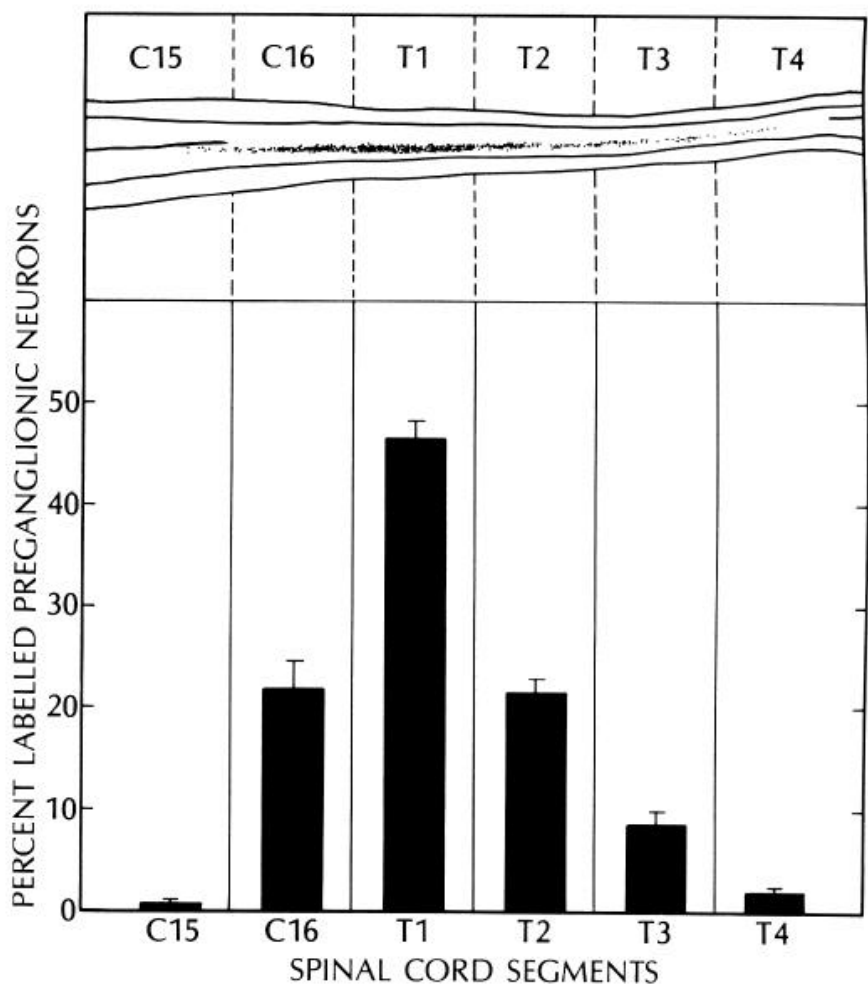

Figure 6. Distribution of labeled preganglionic neurons in the spinal cord after HRP was applied to the cut sympathetic trunk just below the $\mathrm{C} 15$ ganglion. Top, Composite camera lucida drawing of longitudinal serial sections of the spinal cord showing the location and density of labeled cells. Labeled preganglionic neurons are restricted to the side of HRP application. Because of clustering and the superposition of some cells, each dot may represent more than 1 cell. Bottom, Segmental distribution of labeled preganglionic neurons in the spinal cord. Segmental boundaries are taken to be midway between each of the dorsal roots. Histograms were obtained from uncorrected counts of labeled neurons in 8 animals; bars indicate SEM. The segments providing innervation to the $\mathrm{C} 15$ ganglion (Fig. 3) are the same as those containing labeled preganglionic neurons. Thus, in addition to providing the anatomical correlate of ganglion cell innervation in the cervical sympathetic chain ganglia, these data suggest that no significant intraspinal pathways are present in the sympathetic preganglionic cell column of the chick.

spinal level and decreases with distance in more rostral and caudal spinal segments. The segmental distribution of labeled neurons was determined in 8 animals by counting the number of labeled cells in every fourth section of the spinal cord. While labeled cells were present in segments $\mathrm{C} 15-\mathrm{T} 4$, the majority of labeled cells was found in segments $\mathrm{C} 16-\mathrm{T} 2$ (Fig. 6). The segmental distribution of labeled preganglionic neurons in the spinal cord is similar to the pattern of ganglion cell innervation that was determined by intracellular recording in cervical ganglia (Fig. 3).

\section{Segmental organization of preganglionic neurons}

Two lines of evidence indicate that the organization of the preganglionic neurons is segmental in nature, i.e., that preganglionic axons exit the spinal cord at the segmental level of their cell bodies. First of all, the similarity in the distribution of labeled preganglionic neurons upon application of HRP to the cut cer-

spinal segment $(C)$. Occasionally, 1 or 2 labeled cells were found in the intermediolateral position of the spinal cord (arrow), where many preganglionic neurons of mammals are located. 


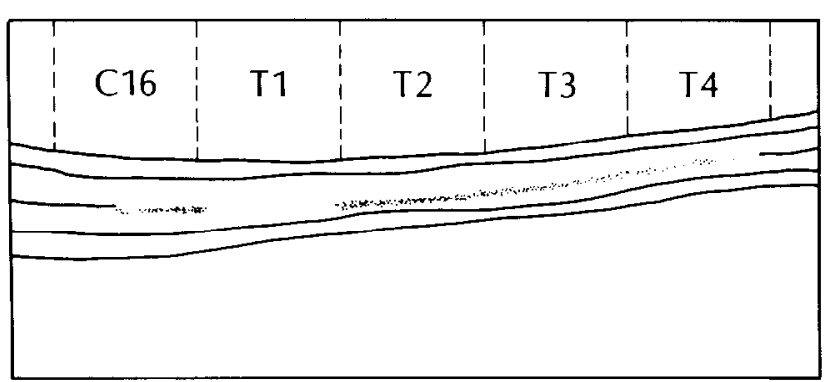

Figure 7. Demonstration that no significant intraspinal pathways are present in the preganglionic cell column. The T1 spinal nerve was cut at its exit from the corresponding bony canal before HRP was applied to the cut sympathetic trunk between the $\mathrm{C} 15$ and $\mathrm{C} 16$ ganglia. This composite camera lucida drawing shows the presence of labeled preganglionic neurons in the spinal cord of such an animal. In none of the 3 animals in which this operation was performed were labeled preganglionic neurons found in the T1 spinal segment.

vical sympathetic trunk and the pattern of ganglion cell innervation determined by intracellular recording suggests that no significant intraspinal pathway is present (Figs. 3,6). The second line of evidence came from studies in which HRP was applied to the cervical sympathetic trunk after the $\mathrm{T} l$ spinal nerve was sectioned at its exit from the spinal cord. In all 3 animals in which this operation was performed, no labeled cells were found in the T1 spinal cord segment, where about half of the total number of labeled preganglionic neurons were normally found (Fig. 7). Thus, in the chick, as in mammals, there is no intraspinal pathway for preganglionic axons (see Rubin and Purves, 1980).

\section{Discussion}

Sympathetic ganglion cells in the chick are innervated in a highly stereotyped pattern. Individual neurons are contacted by a subset of the spinal segments that supply the ganglion as a whole. The subset of spinal segments innervating each ganglion cell is nearly always contiguous, with 1 segment providing the dominant innervation to the cell. This pattern of ganglion cell innervation is very similar to that of the mammal (Lichtman and Purves, 1980; Njå and Purves, 1977a; Rubin, 1985a-c).

The notion that sympathetic ganglion cell innervation of the mammal is selective is based on the following observations. First, stimulation of each of the upper thoracic ventral roots supplying innervation to the superior cervical ganglion elicits qualitatively different end-organ effects (Langley, 1892, 1900; Lichtman et al., 1979; Njå and Purves, 1977a). Thus, for example, stimulation of $\mathrm{T} 1$ ventral roots results in dilation of the pupil and widening of the palpebral fissure, whereas stimulation of T4 ventral roots elicits vasoconstriction in the ear. The systematically graded innervation of individual ganglion cells by a contiguous subset of spinal segments is presumably the cellular basis of the end-organ responses elicited in vivo by stimulation of each ventral root. In accord with this view is the finding that ganglion cells projecting to the same target region receive the same segmental innervation. Other evidence in support of selective innervation in sympathetic ganglion cells of the mammal has come from re-innervation studies. Upon transection of the cervical sympathetic trunk and re-inncrvation of the supcrior cervical ganglion, the stereotyped pattern of ganglion cell innervation and the characteristic pattern of end-organ responses to ventral root stimulation are restored (Langley, 1895, 1897; Njå and Purves, 1977b, 1978).

Although re-innervation studies have not been done in the chick sympathetic system, Langley studied the in vivo responses of sympathetic end-organs of the chick to stimulation of each of the spinal nerves that contribute to the innervation of the sympathetic chain ganglia (Langley, 1904). Among Langley's findings that indicated the similarity of the general organization of the sympathetic system of the chick and mammal, one that deserves special attention is the observation that preganglionic axons arising from successive spinal nerves supply successive but largely overlapping regions of the body. For instance, stimulation of the C16 spinal nerve elicited stronger feather movement on the head and upper part of the neck than in the lower neck. Stimulation of the T1 spinal nerve, in contrast, elicited strong feather movement in the lower neck and anterior part of the wing, whereas stimulation of the T2 spinal nerve elicited feather movement in the posterior part of the wing and the upper part of the thorax. The present results indicate that the activation of the $\mathrm{C} 12$ and $\mathrm{C} 15$ ganglia is responsible, at least in part, for the sympathetic responses elicited in the lower neck and the wing by stimulation of spinal nerves C16-T2. Although both ganglia are innervated by an almost identical set of spinal cord segments, neurons in the $\mathrm{Cl} 2$ ganglion are dominated more by preganglionic axons arising from $\mathrm{C} 16$ and $\mathrm{T} 1$, whereas neurons in the $\mathrm{C} 15$ ganglion, a major ganglion that supplies the brachial region, are largely dominated by preganglionic axons arising from $\mathrm{T} 1$ and $\mathrm{T} 2$. It therefore appears that ganglion cells that are innervated by preganglionic neurons of the same spinal cord level project to the same target region (see Lichtman et al., 1979). The striking similarity in the innervation of avian and mammalian sympathetic ganglia suggests that the rules that underlic the spccificity of synapsc formation in the sympathetic system of the 2 species are the same.

The mechanisms that give rise to highly ordered connections in sympathetic ganglia during development are not known. Although mechanisms such as mechanical guidance and timing will most certainly play a role in the generation of highly ordered innervation patterns, a mechanism that is consistent with the results on the selective re-innervation of ganglia ( $\mathrm{Njå}$ and Purves, $1977 \mathrm{~b}, 1978$ ) and ganglia transplants (Purves et al., 1981) is that pre- and postganglionic neurons are recognized by specific surface labels, acquired by their early positions along the neuraxis.

\section{References}

DeOlmos, J., H. Hardy, and L. Heimer (1978) The afferent connections of the main and the accessory olfactory bulb formations in the rat: An experimental HRP study. J. Comp. Neurol. 18: 213-244.

Ginsborg, B. L. (1960) Spontaneous activity in muscle fibers of the chick. J. Physiol. (Lond.) 150: 707-717.

Guth, L., and J. J. Bernstein (1961) Selectivity in the reestablishment of synapses in the superior cervical sympathetic ganglion of the cat. Exp. Neurol. 4: 59-69.

Langley, J. N. (1892) On the origin from the spinal cord of the cervical and upper thoracic sympathetic fibres, with some observations on white and grey rami communicantes. Philos. Trans. R. Soc. London 183: 85-124.

Langley, J. N. (1895) Note on the regeneration of preganglionic fibres of the sympathetic system. J. Physiol. (Lond.) 18: 280-284.

Langley, J. N. (1897) On the regeneration of preganglionic and postganglionic visceral nerve fibres. J. Physiol. (Lond.) 22: 215-230.

Langley, J. N. (1900) Notes on the regeneration of the preganglionic fibres in the sympathetic system. J. Physiol. (Lond.) 25: 417-426.

Langley, J. N. (1904) On the sympathetic system of birds, and on the muscles which move the feathers. J. Physiol. (Lond.) 30: 221-252.

Levi-Montalcini, R. (1950) The origin and development of the visceral system in the spinal cord of the chick embryo. J. Morphol. 81: 253282.

Lichtman, J. W., and D. Purves (1980) The elimination of redundant preganglionic innervation to hamster sympathetic ganglion cells in early postnatal life. J. Physiol. (Lond.) 301: 213-228.

Lichtman, J. W., D. Purves, and J. W. Yip (1979) On the purpose of selective innervation of guinea-pig superior cervical ganglion cells. J. Physiol. (Lond.) 292: 69-84.

Lichtman, J. W., D. Purves, and J. W. Yip (1980) Innervation of 
sympathetic neurones in the guinea-pig thoracic chain. J. Physiol. (Lond.) 298: 285-299.

Maehlen, J., and A. Njå (1981) Selective synapse formation during sprouting and after partial denervation of the guinea-pig superior cervical ganglion. J. Physiol. (Lond.) 319: 555-567.

Njå, A., and D. Purves (1977a) Specific innervation of guinea-pig superior cervical ganglion cells by preganglionic fibres arising from different levels of the spinal cord. J. Physiol. (Lond.) 264: 565-583.

$\mathrm{Nja}$, A., and D. Purves (1977b) Re-innervation of guinea-pig superior cervical ganglion cells by preganglionic fibres arising from different levels of the spinal cord. J. Physiol. (Lond.) 273: 633-651.

Njå, A., and D. Purves (1978) Specificity of initial synaptic contacts on guinea-pig superior cervical ganglion cells during regeneration of the cervical sympathetic trunk. J. Physiol. (Lond.) 281: 45-62.

Oppenheim, R. W., and I. W. Chu-Wang (1983) Aspects of naturallyoccurring motoneuron death in the chick during embryonic development. In Somatic and Autonomic Nerve-Muscle Interactions, G. Burnstock and G. Vrbová, eds., pp. 58-107, Elsevier, Amsterdam.

Purves, D., W. Thompson, and J. W. Yip (1981) Re-innervation of ganglia transplanted to the neck from different levels of the guineapig sympathetic chain. J. Physiol. (Lond.) 313: 49-63.

Rubin, E. (1985a) Development of the rat superior cervical ganglion: Ganglion cell maturation. J. Neurosci. 5: 673-684.

Rubin, E. (1985b) Development of the rat superior cervical ganglion: Ingrowth of preganglionic axons. J. Neurosci. 5: 685-696.

Rubin, E. (1985c) Development of the rat superior cervical ganglion: Initial stages of synapse formation. J. Neurosci. 5: 697-704.

Rubin, E., and D. Purves (1980) Segmental organization of sympathetic preganglionic neurons in the mammalian spinal cord. J. Comp. Neurol. 192: 163-174.

Terni, T. (1924) Ricerche anatomiche sul sistema nervoso autonomo degli Uccelli. Arch. Ital. Anat. Embriol. 20: 433-510.

Yip, Joseph W. (1986b) Migratory patterns of sympathetic ganglioblasts and other neural crest derivatives in chick embryos. J. Neurosci. 6: 3465-3473.

Yntema, C. L., and W. S. Hammond (1947) The development of the autonomic nervous system. Biol. Rev. 22: 344-359. 